\title{
High congruence of isotope sewage signals in multiple marine taxa
}

\author{
$\underline{\text { Rod M. Connolly }}{ }^{1 *}$, Daniel Gorman ${ }^{2}$, Jeremy S. Hindell ${ }^{3}$, Timothy N. Kildea ${ }^{4}$, Thomas A. Schlacher ${ }^{5}$ \\ ${ }^{1}$ Australian Rivers Institute - Coast \& Estuaries, and School of Environment, Griffith University, Gold Coast Campus, QLD \\ 4222, Australia.r.connolly@griffith.edu.au \\ ${ }^{2}$ South Australian Research and Development Institute, West Beach, SA 5024, Australia. Daniel.Gorman@sa.gov.au \\ ${ }^{3}$ Department of Sustainability and Environment Victoria, Heidelberg, Vic, 3084, Australia. \\ jeremy.s.hindell@dse.vic.gov.au \\ ${ }^{4}$ Australian Water Quality Centre, SA Water, Adelaide, SA 5001, Australia. Timothy.Kildea@sawater.com.au \\ ${ }^{5}$ Faculty of Science, Health \& Education. University of the Sunshine Coast. Maroochydore DC, Q-4558. Australia. \\ tschlach@usc.edu.au \\ * corresponding author: r.connolly@griffith.edu.au
}

\begin{abstract}
Assessments of sewage pollution routinely employ stable nitrogen isotope analysis $\left(\delta^{15} \mathrm{~N}\right)$ in biota, but multiple taxa are rarely used. This single species focus leads to underreporting of whether derived spatial N patterns are consistent. Here we test the question of 'reproducibility', incorporating 'taxonomic replication' in the measurement of $\delta^{15} \mathrm{~N}$ gradients in algae, seagrasses, crabs and fish with distance from a sewage outfall on the Adelaide coast (southern Australia). Isotopic sewage signals were equally strong in all taxa and declined at the same rate. This congruence amongst taxa has not been reported previously. It implies that sewage-N propagates to fish via a tight spatial coupling between production and consumption processes, resulting from limited animal movement that closely preserves the spatial pollution imprint. In situations such as this where consumers mirror pollution signals of primary producers, analyses of higher trophic levels will capture a broader ambit of ecological effects.
\end{abstract}

Keywords: sewage; nitrogen isotopes; monitoring; spatial gradients; coastal waters;

\section{Introduction}

Nitrogen is pivotal in shaping the structure and function of natural systems at multiple levels of ecological organisation (Conley et al., 2009). Humankind has massively altered the cycling and mobility of nitrogen in the biosphere, adding unprecedented amounts of bioavailable $\mathrm{N}$ to ecosystems, most of it since the second half of the last century (Canfield et al., 2010; Vitousek et al., 1997). These anthropogenic inputs of $\mathrm{N}$ can have serious and widespread environmental consequences, altering productivity, diversity, trophic connections, species composition, organism health, and habitat quality (Cloern, 2001; Deegan et al., 2012). 
Excess nitrogen from human sources is a component of a suite of stressors causing impacts that can be severe and widespread in coastal waters (Lotze et al., 2006; Reopanichkul et al., 2009). Fertilization of nearshore marine waters with human-derived nutrients is mainly the result of changing land-use, most notably the widespread and escalating urbanisation of coastal areas (Nixon and Buckley, 2002). Ecological effects of nutrient inputs therefore often centre on coastal cities (Diaz and Rosenberg, 2008; Oczkowski et al., 2009).

Nitrogen contained in human metabolic waste products is a major component of nutrient inputs to coastal waters (McClelland et al., 1997; Schlacher et al., 2005), and monitoring the effects of sewage entering marine ecosystems has become an important activity (Costanzo et al., 2001). One of the most widely applied techniques to identify the presence of sewage- $\mathrm{N}$ is the analysis of stable nitrogen isotopes in the tissues of biota putatively exposed to inorganic sewage- $\mathrm{N}$ or assimilating it from their diet (Cabana and Rasmussen, 1996; Pitt et al., 2009). The technique is based on predictable differences in the abundance of the heavy $\left({ }^{15} \mathrm{~N}\right)$ and light $\left({ }^{14} \mathrm{~N}\right)$ isotopes between sewage and other $\mathrm{N}$ sources such as fertilizers; nitrogen in treated wastewater is generally enriched in the heavier isotope ${ }^{15} \mathrm{~N}$, and monitoring of sewage inputs exploits this higher concentration of ${ }^{15} \mathrm{~N}$ (Cole et al., 2004; Heaton, 1986).

Studies aimed at detecting nitrogen discharged in sewage based on stable nitrogen isotope ratios $\left(\delta^{15} \mathrm{~N}\right.$ ) in organisms have drawn upon a wide variety of taxa, including algae (Dailer et al., 2010; Fernandes et al., 2012), rooted macrophytes (Cole et al., 2004; McClelland et al., 1997), sessile invertebrates (Carmichael et al., 2008; Carmichael et al., 2012; Fertig et al., 2010; Fertig et al., 2009; Risk et al., 2009), motile invertebrates (Bucci et al., 2007), and fish (Hoffman et al., 2012; Schlacher et al., 2005) . Most report that the chosen taxon is 'suitable' as an ecological indicator of sewage- $\mathrm{N}$, and that spatial patterns in relation to sewage sources can be mapped, or at least interpreted in a spatial context of known inputs (Costanzo et al., 2001; Northington and Hershey, 2006).

Investigations that include multiple species from different functional groups or from different trophic levels are less common (but see for example Pitt et al., 2009). Arguably, this lack of taxonomic and functional 'replication' raises two questions in relation to the assessment of isotopic sewage- $\mathrm{N}$ distributions: 1.) Are spatial patterns of the sewage signal reproducible using different taxa? ('repeatability'), and 2.) Are effect sizes (i.e. the magnitude of the isotopic sewage signal) comparable among taxa? ('sensitivity'). Here we examine both these questions using a two-staged approach: i) we first test for differences in the strength of the $\delta^{15} \mathrm{~N}$ gradient - comparing changes of $\delta^{15} \mathrm{~N}$ in multiple taxa with distance from a defined point source of sewage inputs in a shallow marine gulf of southern 
Australia, and ii) we then examine the generality of our findings by comparisons with spatial $\delta^{15} \mathrm{~N}$ gradients in other settings where multiple taxa have been used to measure sewage- $\mathrm{N}$ gradients.

\section{Methods}

Gulf St Vincent (GSV) is a large, shallow marine embayment in southern Australia, bordering the city of Adelaide (Fig. 1). The general circulation of the gulf is clockwise, the western shores are bordered by mangroves, and the seafloor consists of a mosaic of bare sand and seagrass meadows and reefs (Jones et al., 2008). The GSC is located in an arid climatic zone where the annual evaporation exceeds rainfall, resulting in limited freshwater inputs from small local creeks and rivers (Shepherd and Sprigg, 1976). This makes discharges of sewage effluent on the eastern shores the main source of nutrients to receiving marine waters. Of the 1,431 tonnes of $\mathrm{N}$ entering the gulf waters from the city of Adelaide, 827 tonnes (58\%) come from waste-water treatment plants (Fernandes et al., 2012). We designed our study to determine spatial gradient of sewage- $\mathrm{N}$ in relation to the largest point source, the Bolivar wastewater treatment plant: it is the main contributor of sewage- $\mathrm{N}$ to the gulf, discharging 509 tonnes of $\mathrm{N}$ per annum, or $62 \%$ of all treated $\mathrm{N}$ discharged in sewage effluents (Fernandes et al., 2012). 

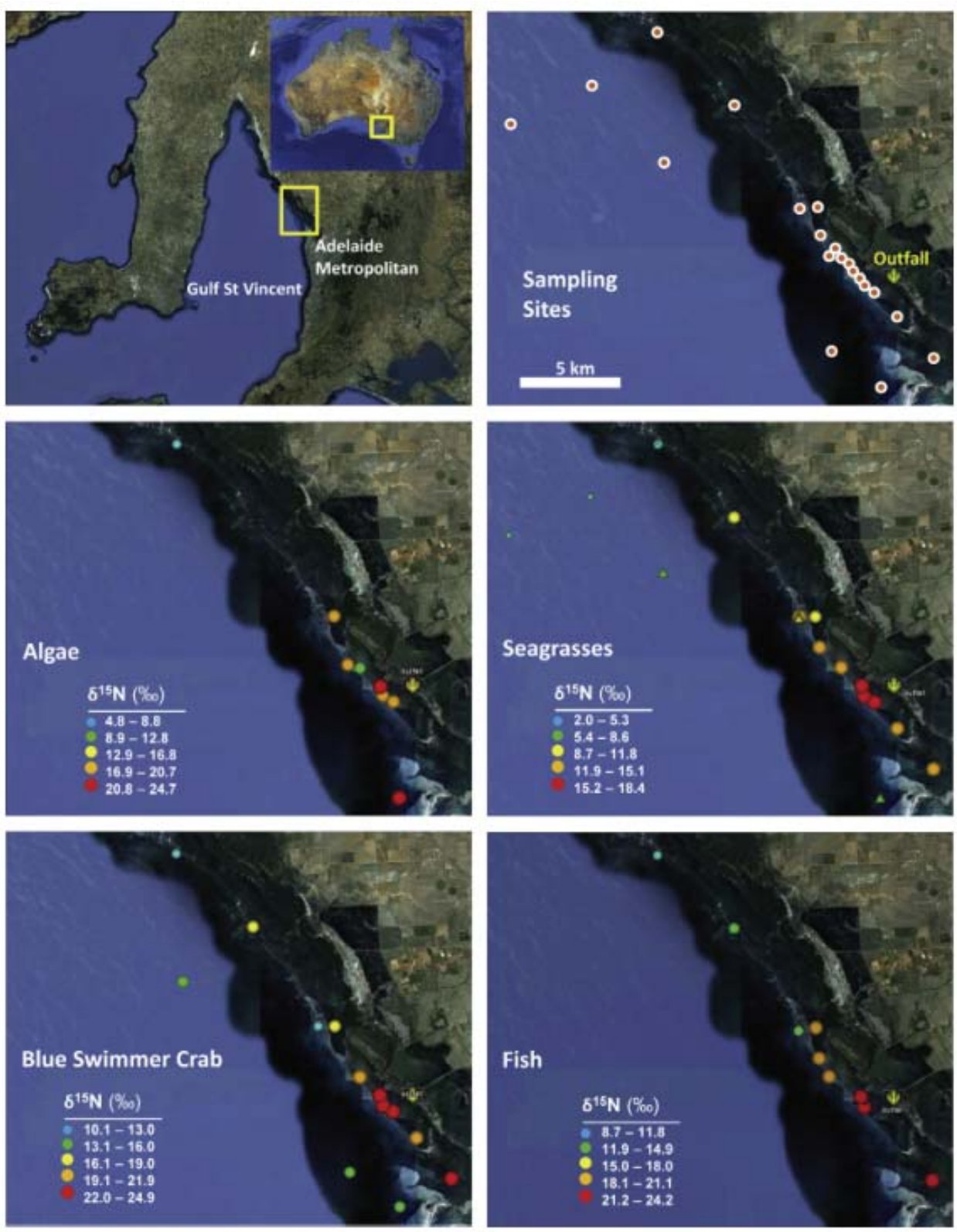

Fig. 1 Location of the study area in Gulf St Vincent of South Australia near the city of Adelaide and map of the sampling stations in relation to the major sewage outfall point on the eastern shores from the Bolivar treatment plant (top row), and distribution of $\delta^{15} \mathrm{~N}$ values in the tissues of marine biota sampled to determine the spatial gradients of sewage-N signals in the nearshore marine waters of the gulf (middle and bottom row). In the seagrass map triangles denote Zostera samples and circles denote Posidonia.

We collected multiple taxa to determine the spatial gradients of the sewage-N signal in relation to the defined sewage outfall of the Bolivar treatment plant (Fig. 1). Biota analysed for tissue $\square^{15} \mathrm{~N}$ included primary producers (the green alga Ulva lactuca and two genera of seagrass, Zostera and Posidonia), mobile benthic invertebrates (the blue swimmer crab Portunus armatus), and pelagic fish (small- 
mouthed hardyhead, Atherinosoma microstoma). Individuals were collected from 33 sites wherever they were present during the austral summer (Jan - Mar).

Muscle tissue was excised from crabs and fish, seagrass blades were cleaned of epiphytes. Samples were analysed on a 20-20 Europa Scientific mass spectrometer at the Stable Isotope Facility of Griffith University. Isotope values are expressed in the del $(\square)$ notation, $\square^{15} \mathrm{~N}$, relative to the international standard of atmospheric nitrogen: $\square{ }^{15} \mathrm{~N}(\%)=\left(\left({ }^{15} \mathrm{~N} /{ }^{14} \mathrm{~N}_{\text {sample }} \div{ }^{15} \mathrm{~N} /{ }^{14} \mathrm{~N}_{\text {standard }}\right)-1\right) \mathrm{x}$ 1000. Precision of duplicate samples was $0.2 \%$. 


\section{Results}

The isotope sewage signal in organisms from the Gulf St Vincent showed a strong spatial gradient that was consistent among multiple taxa (Fig. 1). The abundance of the heavier isotope ${ }^{15} \mathrm{~N}$ declined significantly with distance from the outfall in the tissues of all taxa examined, consistent with a gradient of decreasing sewage-N contributions further from the point source (Figs. $1 \& 2$ ).
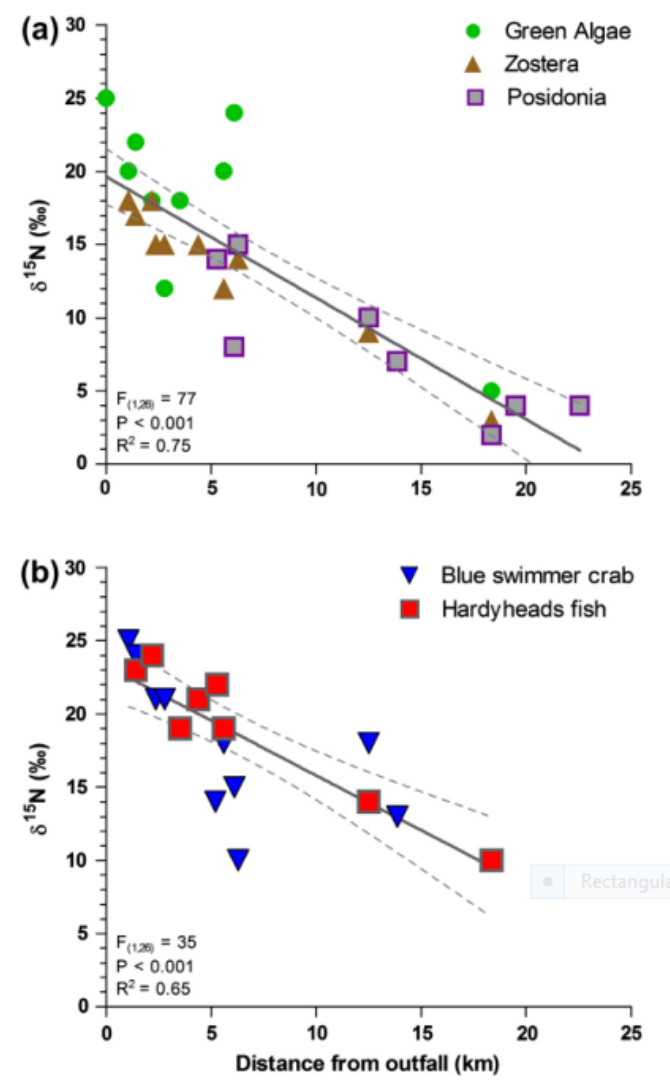

Fig. 2 Decline in tissue $\delta^{15} \mathrm{~N}$ at increasing distance from the sewage outfall in a) autotrophs (the green alga, Ulva lactuca, and two genera of seagrass (Posidonia, Zostera), and b) consumers (the portunid crab Portunus armatus, and hardyheads, Atherinosoma microstoma, a small pelagic fish).

This relationship between distance from the treatment plant's outfall and organism $\delta^{15} \mathrm{~N}$ values did not deviate significantly from a linear model in any species analysed (Runs test: $\min . p=0.236$ ). Tissue concentrations of ${ }^{15} \mathrm{~N}$ declined at similar rates in all species, irrespective of their trophic position, or the mode of nitrogen acquisition in plants. There was no significant $\left(\mathrm{F}_{4,39}=0.28, p=0.88\right)$ difference in regression slopes among the five taxa analysed, with a common (pooled) slope estimate of -0.74 ; this translates to a decrease of $1 \%$ in $\delta^{15} \mathrm{~N}$ for every $1.33 \mathrm{~km}$ in distance from the outfall. 
This consistency in the strength and direction of the sewage-N gradient among taxa has not been reported previously (Table 1, Fig. 3). On the contrary, taxa usually differ considerably in whether they express a sewage gradient (i.e. non-zero regression slopes), and if they do, they differ in the rate at which the isotopic sewage signal declines away from the source (Table 1, Fig. 3).

\section{Discussion}

We show that 1.) multiple taxa from different functional groups express spatial patterns of sewage-N at comparative levels (i.e. all species showed significant spatial declines in their ${ }^{15} \mathrm{~N}$ tissue concentrations), and 2.) a very similar spatial gradient is reproduced by different taxa (i.e. essentially the same rates of ${ }^{15} \mathrm{~N}$ decline). These findings are remarkable because other studies that have employed multiple taxa to assess spatial patterns of sewage-N show inconsistencies between taxa in terms of detecting a gradient, in terms of the strength of the inferred gradient, or both (Table 1, Fig. 3). Also, compared with other published accounts of variations in $\delta^{15} \mathrm{~N}$ in relation to sewage outfalls in multiple taxa, we report the strongest gradient of a sewage signature in nearshore marine biota to date (Table 1).

With the exception of Pitt et al. (2009), who also measured significant gradients in the three taxa they examined, species are generally reported to vary considerably in how strongly the spatial sewage pattern is expressed (Table 1). For example, Hansson et al. (1997) report strong gradients for zooplankton and epibenthic mysids, but failed to detect a pattern consistent with a sewage $\mathrm{N}$-source in the smallest and largest size class of herring. Both Conlan et al (2006) and Gartner et al. (2002) found declines in organism $\delta^{15} \mathrm{~N}$ consistent with a spatial cline of the sewage signal in only a single species out of 5 and 7 examined (Table 1).

Our result of sewage-N gradients across all taxa is also unexpected because the taxa analysed differ fundamentally in their mode of nitrogen acquisition and subsequent rates of tissue turnover of the assimilated N. Primary producers incorporate inorganic $\mathrm{N}$ in dissolved form, whereas animals assimilate $\mathrm{N}$ from dietary organic particulates. Uptake of $\mathrm{N}$ in algae occurs only via their thalli, whereas seagrasses have a complementary uptake route via their roots (Touchette and Burkholder, 2000). The fact that all species, irrespective of uptake routes or the form of nitrogen used, carried a clear sewage isotope signal in their tissue indicates that sewage- $\mathrm{N}$ enters the food via several primary producers to be transferred upwards. 
Table 1 Synopsis of spatial gradients in nitrogen isotopic sewage signals measured in organism away from defined point sources of sewage inputs to nearshore estuarine/marine waters. Compilation includes studies that determined spatial patterns of $\delta^{15} \mathrm{~N}$ in at least two different taxa with a minimum samples size of $\mathrm{n}=8$. Statistics are for log-linear models of organism $\delta^{15} \mathrm{~N}$ in relation to distance from the outfall.

\begin{tabular}{|c|c|c|c|c|c|c|c|c|c|c|}
\hline Source & Location & Habitat & Load & No. Species / Taxa & Spatial scale & $\begin{array}{c}\text { Max. } \delta^{15} \mathbf{N} \\
\text { contrast }\end{array}$ & $\begin{array}{l}\text { Slopes } \\
\text { (range) }\end{array}$ & $\begin{array}{c}\text { No. } \\
\text { slopes }>0\end{array}$ & $\begin{array}{c}\mathbf{R}^{2} \\
\text { (range) }\end{array}$ & $\begin{array}{c}\text { ANCOVA } \\
\text { (equal slopes?) }\end{array}$ \\
\hline $\begin{array}{l}\text { Hansson et } \\
\text { al. (1997) }\end{array}$ & $\begin{array}{l}\text { Northern } \\
\text { Baltic }\end{array}$ & coastal sea & na & $\begin{array}{l}\text { 7: invertebrates 2x (zooplankton, mysids } \\
\text { (Mysis mixta \& M. relicta); fishes 5x (smelt, } \\
\text { Osmerus eperlans, sprat, Sprattus sprattus, \& } \\
\text { herring, Clupea harengus, } 3 \text { size classes). }\end{array}$ & $\sim 29 \mathrm{~km}$ & 8.9 & $1.01-19.90$ & $5(72 \%)$ & $\begin{array}{l}0.03- \\
0.78\end{array}$ & $\begin{array}{l}\mathrm{F}_{6,69}=3.15 \\
\mathrm{P}=0.009\end{array}$ \\
\hline $\begin{array}{l}\text { Tucker et } \\
\text { al. (1999) }\end{array}$ & Boston Harbor & $\begin{array}{l}\text { estuarine / } \\
\text { embayment; semi- } \\
\text { exposed }\end{array}$ & $\begin{array}{l}\sim 11,700 \\
\mathrm{t} \mathrm{N} \mathrm{y}^{-1}\end{array}$ & $\begin{array}{l}\text { 2: macroalgae (Ulva \& Enteromorpha); blue } \\
\text { mussels (Mytilus edulis) }\end{array}$ & $\sim 17 \mathrm{~km}$ & 8.3 & $1.75-6.93$ & $1(50 \%)$ & $\begin{array}{l}0.23- \\
0.60\end{array}$ & $\begin{array}{l}F_{1,12}=3.74 \\
P=0.077\end{array}$ \\
\hline $\begin{array}{l}\text { Gartner et } \\
\text { al. }(2002)\end{array}$ & $\begin{array}{l}\text { Western } \\
\text { Australia }\end{array}$ & $\begin{array}{l}\text { open coast, nearshore } \\
\text { reef; exposed to semi- } \\
\text { exposed }\end{array}$ & $\begin{array}{l}140 \mathrm{ML} \\
\mathrm{d}^{-1}\end{array}$ & $\begin{array}{l}\text { 5: macroalgae } 3 x \text { (Ulva australis, Vidalia sp., } \\
\text { Ecklonia radiata); invertebrates } 2 x \text { (sponge, } \\
\text { Clathria sp., ascidian, Pyura australis) }\end{array}$ & $\sim 19 \mathrm{~km}$ & 6.8 & $1.4-4.82$ & $1(20 \%)$ & $\begin{array}{l}0.05- \\
0.52\end{array}$ & $\begin{array}{l}F_{4,48}=1.29 \\
P=0.29\end{array}$ \\
\hline $\begin{array}{l}\text { Conlan et } \\
\text { al. }(2006)\end{array}$ & Antarctica & subtidal, exposed & $\begin{array}{l}0.6- \\
2.1 \mathrm{ML} \\
\mathrm{d}^{-1}\end{array}$ & $\begin{array}{l}\text { 7: invertebrates } 6 x \text { (burrowing clam, ascidian, } \\
\text { soft coral, sea star, sea urchin, nemertean } \\
\text { worm); fish (Trematomus bernacchii) }\end{array}$ & $<1 \mathrm{~km}$ & 7.0 & $0.15-18.02$ & $1(14 \%)$ & $\begin{array}{l}0.01- \\
0.43\end{array}$ & $\begin{array}{l}\mathrm{F} 6,98=2.57 \\
\mathrm{P}=0.02\end{array}$ \\
\hline $\begin{array}{l}\text { Pitt et al. } \\
\text { (2009) }\end{array}$ & $\begin{array}{l}\text { SE Australia, } \\
\text { Brisbane } \\
\text { Estuary }\end{array}$ & estuary, sheltered & $\int_{-1}^{303} \mathrm{t} \mathrm{N} \mathrm{y}$ & $\begin{array}{l}\text { 3: algae (filamentous algae on mangrove } \\
\text { pneumatophores); mangrove leaves (Avicennia } \\
\text { marina); shore crabs (Australoplax tridentata } \\
\text { \& Parasesarma eythrogramma) }\end{array}$ & $\sim 41 \mathrm{~km}$ & 26.3 & $4.30-8.80$ & $3(100 \%)$ & $\begin{array}{l}0.41- \\
0.69\end{array}$ & $\begin{array}{l}F 2,168=9.78 \\
P<0.001\end{array}$ \\
\hline This study & $\begin{array}{l}\text { Gulf St } \\
\text { Vincent, } \\
\text { South } \\
\text { Australia }\end{array}$ & $\begin{array}{l}\text { embayment, semi- } \\
\text { exposed }\end{array}$ & $\begin{array}{l}\text { Mean } \\
\text { flow }=93 \\
\mathrm{ML} \mathrm{d}^{-1} ; \\
\mathrm{Load}^{2} \\
487 \\
\mathrm{t} \mathrm{N} \mathrm{y}^{-1}\end{array}$ & $\begin{array}{l}\text { 5: macroalgae (Ulva lactuca); seagrasses } 2 \mathrm{x} \\
\text { (Zostera spp., Posidonia spp.); blue swimmer } \\
\text { crab, Portunus armatus); fish (Hardyheads, } \\
\text { Atherinosoma microstoma) }\end{array}$ & $\sim 23 \mathrm{~km}$ & 20.0 & $11.50-17.72$ & $5(100 \%)$ & $\begin{array}{l}0.46- \\
0.86\end{array}$ & $\begin{array}{l}\mathrm{F} 4,39=0.31 \\
\mathrm{P}=0.87\end{array}$ \\
\hline
\end{tabular}


Nitrogen is turned over quickly in algal tissue, in the local situation reaching equilibrium with DIN within 8 days (Fernandes et al., 2012). Tissue turnover in seagrasses and animals is considerably slower and more variable, typically ranging from weeks to months (Gaston and Suthers, 2004; Hesslein et al., 1993; Lepoint et al., 2002). Because tissue turnover rates determine the time interval over which biota integrate the sewage-N signals they have been exposed to, the consistency of the isotope patterns documented in this study suggest that the wastewater imprint in the receiving waters fronting the Adelaide metropolitan coast is a persistent feature. In other settings, smaller and shortlived nitrogen and sewage plumes have been traced in coastal waters (Connolly et al., 2009; Gaston et al., 2006; Schlacher et al., 2008), including ${ }^{15} \mathrm{~N}$ abundance in beach clams exposed to pulsed outflows from a nearby estuary (Schlacher and Connolly, 2009).

We found that isotopic signals of sewage-N in primary producers were transferred to mobile consumers, including fish (Figs. 2 \& 3). This upwards movement of an isotopic pattern through the food web to fishes is not unusual (e.g. Hobson et al., 2012). Mechanistically it depends on two fundamental conditions to be met: i) the diet of fish and other consumers includes plants that have incorporated the sewage-N (a 'dietary match'), and ii) consumers move little between feeding locations ('site fidelity'). In a trophic context, producers and consumers are spatially coupled in such situations where inorganic $\mathrm{N}$ (from sewage or other sources) enters plants as an inorganic substrate to be transferred to consumers with little spatial dispersion of the latter. Such consistent consumer-diet relationships (sensu Vanderklift and Wernberg, 2010) appear to operate in the nearshore waters of Gulf St Vincent, resulting in the closely matched spatial patterns between mobile consumers and sessile algae and plants.

Coastal fishes can have pronounced site fidelity (Skinner et al., 2012). More generally, when animals preserve spatial differences in isotope values over prolonged periods, stable isotope analysis becomes a tool to determine animal movement (Hobson, 1999). In our situation, the close match in isotope gradients between sessile plants and mobile consumers strongly suggests that movement of crabs and fish is limited; sewage-N is transferred locally in the food web with conservative dispersion away from the source (Fig. 2). 

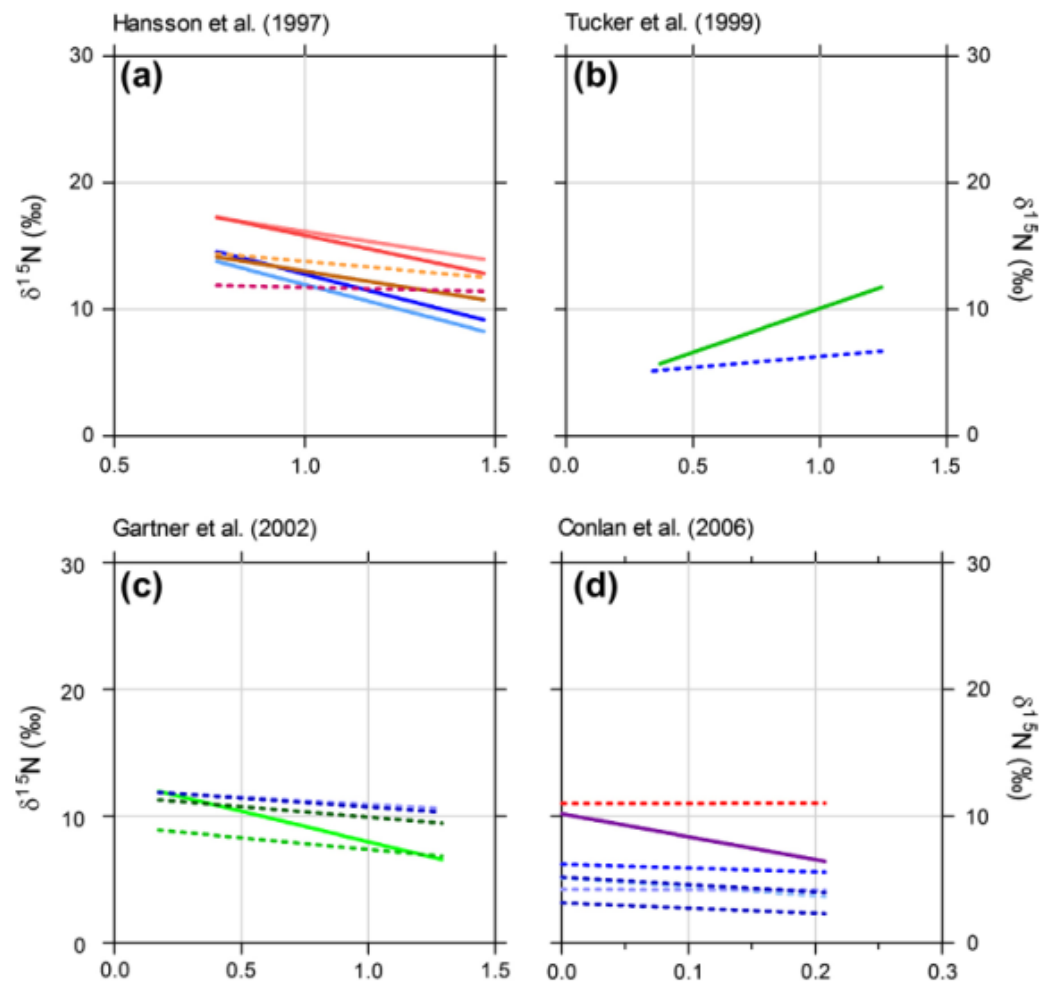

Conlan et al. (2006)
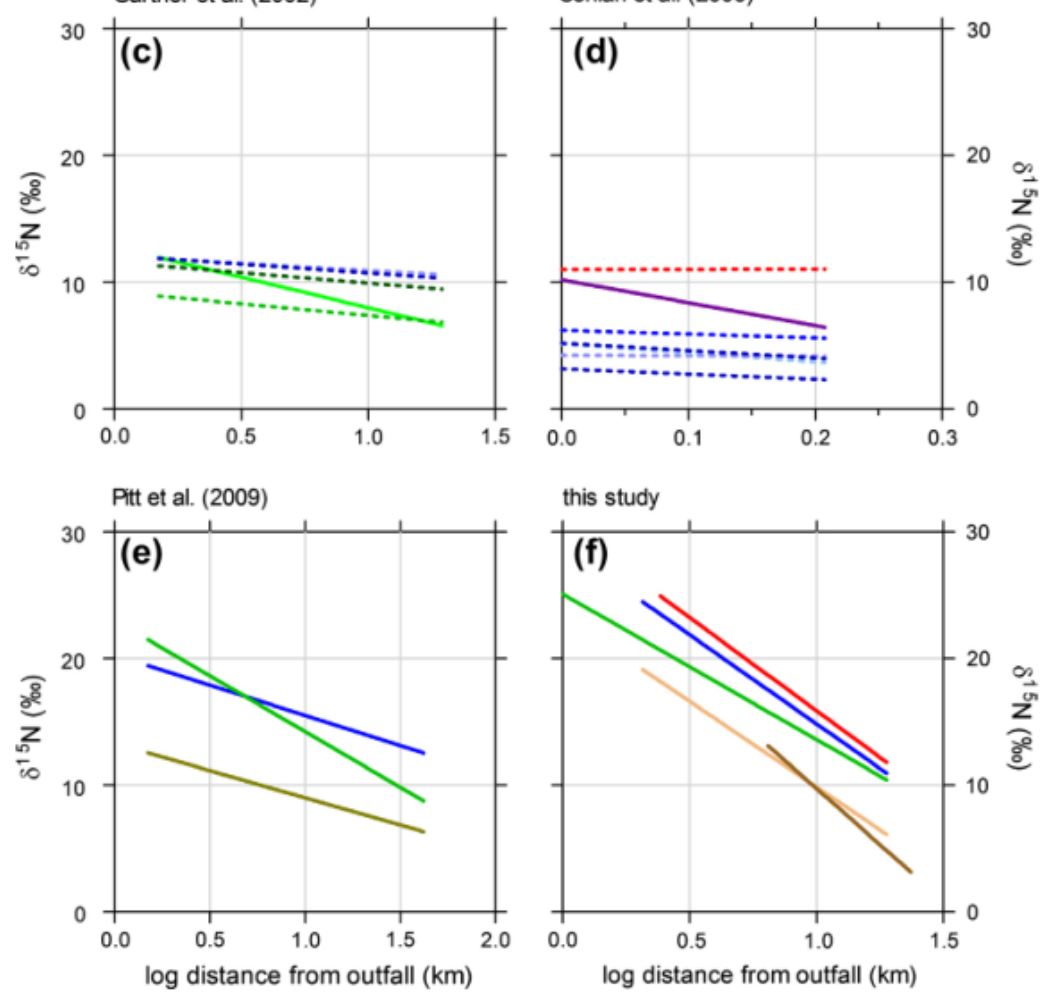

Fig. 3 Relationship between $\delta^{15} \mathrm{~N}$ in biota and distance from defined sewage outfall points in marine waters. Regression lines are shown for each taxon measured within a study: shades of green denote algae, brown colours rooted macrophytes, blues are for invertebrates and red shades for fishes; taxa included in each study are listed in Table 1 which also contains regression statistics for each panel shown here. Solid lines have slopes $>0$ (at $\mathrm{P}<0.05$ ), whereas dashed lines have slopes not significantly different from zero $(\mathrm{P}>0.05)$.

The sewage-N signal was equally strong in crustaceans and fish as it was in autotrophs, providing unequivocal evidence that anthropogenic nitrogen is transferred upwards through the food chain in this system. Fundamentally, this transfer of $\mathrm{N}$ can have two, opposing, ecological consequences for consumers: positive effects in the form of greater secondary production and a flow-on effect of enhanced biological carbon sequestration in the system supplied with anthropogenic $\mathrm{N}$; negative effects where the health and fitness of organisms becomes impaired (Schlacher et al., 2007), or where 
habitats and ecosystems are degraded as a consequence of massive and persistent nutrient loadings (Diaz and Rosenberg, 2008). Elevated tissue ${ }^{15} \mathrm{~N}$ concentrations are reliable indicators of the presence of assimilated sewage-N in organisms (Schlacher et al., 2005), but do not necessarily by themselves imply impaired health in all cases. Measurements of assimilated sewage-N represent a surrogate for complex contaminant pathogen mixtures released into the system via sewage. The specific pathological and chemical components within sewage effluent are not necessarily identified, but may be responsible for the impaired health in fish (sensu Mondon et al., 2001).

Lower water quality may contribute to the decline of seagrass meadows and coastal fisheries (Lotze et al., 2006; Orth et al., 2006; Waycott et al., 2009), but anthropogenic nutrients that are transferred to coastal consumers (sensu Connolly et al., 2009) also stimulate fisheries production (Oczkowski et al., 2009). Fisheries productivity has increased over time in areas under the influence of land-derived nutrient enrichment, and 'anthropogenically enhanced fisheries' can depend strongly on nutrient inputs from sewage and fertilizers (Oczkowski et al., 2009) .

Indubitably, the growing nutrient enrichment of coastal marine waters is of concern (Cloern, 2001; Wulff et al., 2011), but the system-wide consequences of reducing nutrient inputs from sewage, including putative impacts on fisheries, may extend beyond simple improvements in water quality. For example, in the Gulf St Vincent, seagrasses are a large nitrogen sink, trapping up to 862 tonnes of $\mathrm{N}$ per year which represents about one-third of all nitrogen inputs; a sizeable fraction (38\%) of that $\mathrm{N}$ is delivered in sewage discharges (Fernandes et al., 2009). Seagrasses are linked to fisheries production, chiefly because of their high tissue replacement (e.g. shedding of leaves) which liberates organic matter to become available for animal consumption (Connolly et al., 2005; Winning et al., 1999). It follows that reductions in nutrient loads through improved wastewater treatment processes may, hypothetically, have knock-on effects on fisheries species via lower carbon sequestration by seagrasses and other primary producers. Such higher 'order effects' are unknown and, if present, need to be carefully weighed against documented impacts of sewage on marine biota (Schlacher et al., 2007) and the broader environmental consequences resulting from inadvertent anthropogenic fertilization of coastal seas (Diaz and Rosenberg, 2008).

\section{Conclusion}

Marina taxa exposed to sewage discharged from a treatment plant displayed spatial gradients in the

${ }^{15} \mathrm{~N}$ content of their tissues that reflected diminishing sewage- $\mathrm{N}$ contributions with distance from an outfall. We incorporated 'taxonomic replication' in the pollution assessment, using multiple taxa to gauge these spatial gradients. In contrast to previous accounts where sewage-N was mapped 
isotopically in multiple taxa, isotope distributions were remarkably consistent amongst taxa. This congruence amongst taxa indicates several features of anthropogenic nitrogen movement in this system: i) sewage $\mathrm{N}$ enters food webs via several primary producers, ii) sewage- $\mathrm{N}$ is transferred up the food chain to fish, and iii) a tight spatial coupling between production and consumption processes resulting from limited animal movement that preserves the spatial sewage imprint.

\section{Acknowledgements}

We thanks R. Diocares for isotope analyses, T. Gaston for assistance in preparing the manuscript and B. Fry for insights through the Griffith University isotope discussion group.

\section{References}

Bucci, J.P., Rebach, S., DeMaster, D., Showers, W.J., 2007. A comparison of blue crab and bivalve delta N-15 tissue enrichment in two North Carolina estuaries. Env Poll 145, 299-308.

Cabana, G., Rasmussen, J.B., 1996. Comparison of aquatic food chains using nitrogen isotopes. Proceedings of the National Academy of Sciences of the United States of America 93, 10844-10847.

Canfield, D.E., Glazer, A.N., Falkowski, P.G., 2010. The evolution and future of earth's nitrogen cycle. Science 330, 192-196.

Carmichael, R.H., Hattenrath, T., Valiela, I., Michener, R.H., 2008. Nitrogen stable isotopes in the shell of Mercenaria mercenaria trace wastewater inputs from watersheds to estuarine ecosystems. Aquatic Biology 4, 99-111.

Carmichael, R.H., Walton, W., Clark, H., 2012. Bivalve-enhanced nitrogen removal from coastal estuaries. Can J Fish Aquat Sci 69, 1131-1149.

Cloern, J.E., 2001. Our evolving conceptual model of the coastal eutrophication problem. Mar Ecol Prog Ser $210,223-253$.

Cole, M.L., Valiela, I., Kroeger, K.D., Tomasky, G.L., Cebrian, J., Wigand, C., McKinney, R.A., Grady, S.P., Carvalho Da Silva, M.H., 2004. Assessment of a $\delta 15 \mathrm{~N}$ isotopic method to indicate anthropogenic eutrophication in aquatic ecosystems. J Environ Qual 33, 124-132.

Conlan, K.E., Rau, G.H., Kvitek, R.G., 2006. $\delta 13 \mathrm{C}$ and $\delta 15 \mathrm{~N}$ shifts in benthic invertebrates exposed to sewage from McMurdo Station, Antarctica. Mar Pollut Bull 52, 1695-1707.

Conley, D.J., Paerl, H.W., Howarth, R.W., Boesch, D.F., Seitzinger, S.P., Havens, K.E., Lancelot, C., Likens, G.E., 2009. Ecology - Controlling eutrophication: Nitrogen and phosphorus. Science 323, 1014-1015.

Connolly, R.M., Hindell, J.S., Gorman, D., 2005. Seagrass and epiphytic algae support nutrition of a fisheries species, Sillago schomburgkii, in adjacent intertidal habitats. Marine Ecology-Progress Series 286, 69-79.

Connolly, R.M., Schlacher, T.A., Gaston, T.F., 2009. Stable isotope evidence for trophic subsidy of coastal benthic fisheries by river discharge plumes off small estuaries. Marine Biology Research 5, 164-171. 
Costanzo, S.D., O'Donohue, M.J., Dennison, W.C., Loneragan, N.R., Thomas, M., 2001. A new approach for detecting and mapping sewage impacts. Mar Pollut Bull 42, 149-156.

Dailer, M.L., Knox, R.S., Smith, J.E., Napier, M., Smith, C.M., 2010. Using $\delta 15 \mathrm{~N}$ values in algal tissue to map locations and potential sources of anthropogenic nutrient inputs on the island of Maui, Hawai'i, USA. Mar Pollut Bull 60, 655-671.

Deegan, L.A., Johnson, D.S., Warren, R.S., Peterson, B.J., Fleeger, J.W., Fagherazzi, S., Wollheim, W.M., 2012. Coastal eutrophication as a driver of salt marsh loss. Nature 490, 388-392.

Diaz, R.J., Rosenberg, R., 2008. Spreading dead zones and consequences for marine ecosystems. Science 321, 926-929.

Fernandes, M., Benger, S., Sharma, S.K., Gaylard, S., Kildea, T., Hoare, S., Braley, M., Irving, A.D., 2012. The use of delta N-15 signatures of translocated macroalgae to map coastal nutrient plumes: improving species selection and spatial analysis of metropolitan datasets. Journal of Environmental Monitoring 14, 2399-2410.

Fernandes, M., Bryars, S., Mount, G., Miller, D., 2009. Seagrasses as a sink for wastewater nitrogen: The case of the Adelaide metropolitan coast. Mar Pollut Bull 58, 303-308.

Fertig, B., Carruthers, T.J.B., Dennison, W.C., Fertig, E.J., Altabet, M.A., 2010. Eastern oyster (Crassostrea virginica) delta N-15 as a bioindicator of nitrogen sources: Observations and modeling. Mar Pollut Bull 60, 1288-1298.

Fertig, B., Carruthers, T.J.B., Dennison, W.C., Jones, A.B., Pantus, F., Longstaff, B., 2009. Oyster and macroalgae bioindicators detect elevated $\delta 15 \mathrm{~N}$ in Maryland's coastal bays. Estuaries and Coasts 32, 773-786.

Gartner, A., Lavery, P., Smit, A.J., 2002. Use of $\delta 15 \mathrm{~N}$ signatures of different functional forms of macroalgae and filter-feeders to reveal temporal and spatial patterns in sewage dispersal. Mar Ecol Prog Ser 235, 63-73.

Gaston, T.F., Schlacher, T.A., Connolly, R.M., 2006. Flood discharges of a small river into open coastal waters: Plume traits and material fate. Estuarine Coastal and Shelf Science 69, 4-9.

Gaston, T.F., Suthers, I.M., 2004. Spatial variation in $\mathrm{d}^{13} \mathrm{C}$ and $\mathrm{d}^{15} \mathrm{~N}$ of liver, muscle and bone in a rocky reef planktivorous fish: the relative contribution of sewage. J Exp Mar Biol Ecol 304, 17-33.

Hansson, S., Hobbie, J.E., Elmgren, R., Larsson, U., Fry, B., Johansson, S., 1997. The stable nitrogen isotope ratio as a marker of food-web interactions and fish migration. Ecology 78, 2249-2257.

Heaton, T.H.E., 1986. Isotopic studies of nitrogen pollution in the hydrosphere and atmosphere: a review. Chem Geol 59, 87-102.

Hesslein, R.H., Hallard, K.A., Ramlal, P., 1993. Replacement of sulphur, carbon, and nitrogen tissue of growing broad whitefish (Coregonus nasus ) in response to a change in diet traced by $\mathrm{d}^{34} \mathrm{~S}, \mathrm{~d}^{13} \mathrm{C}$, and $\mathrm{d}^{15} \mathrm{~N}$. Can $\mathrm{J}$ Fish Aquat Sci 50, 2071-2076.

Hobson, K.A., 1999. Tracing origins and migration of wildlife using stable isotopes: a review. Oecologia 120, 314-326.

Hobson, K.A., Ofukany, A., Soto, D.X., Wassenaar, L.I., 2012. An isotopic baseline (delta C-13, delta N-15) for fishes of Lake Winnipeg: Implications for investigating impacts of eutrophication and invasive species. Journal of Great Lakes Research 38, 58-65.

Hoffman, J.C., Kelly, J.R., Peterson, G.S., Cotter, A.M., Starry, M.A., Sierszen, M.E., 2012. Using $\delta 15$ N in Fish Larvae as an Indicator of Watershed Sources of Anthropogenic Nitrogen: Response at Multiple Spatial Scales. Estuaries and Coasts, 1-15. 
Jones, G.K., Connolly, R.M., Bloomfield, A.L., 2008. Ecology of fish in seagrass, in: Shepherd, S.A., Bryars, S., Kirkegaard, I., Harbison, P., Jennings, J.T. (Eds.), Natural history of Gulf St Vincent. Royal Society South Australia, Adelaide, pp. 148-161.

Lepoint, G., Defawe, O., Gobert, S., Dauby, P., Bouquegneau, J.M., 2002. Experimental evidence for N recycling in the leaves of the seagrass Posidonia oceanica. J Sea Res 48, 173-179.

Lotze, H.K., Lenihan, H.S., Bourque, B.J., Bradbury, R.H., Cooke, R.G., Kay, M.C., Kidwell, S.M., Kirby, M.X., Peterson, C.H., Jackson, J.B.C., 2006. Depletion degradation, and recovery potential of estuaries and coastal seas. Science 312, 1806-1809.

McClelland, J.W., Valiela, I., Michener, R.H., 1997. Nitrogen-stable isotope signatures in estuarine food webs: A record of increasing urbanization in coastal watersheds. Limnol Oceanogr 42, 930-937.

Mondon, J.A., Duda, S., Nowak, B.F., 2001. Histological, growth and 7-ethoxyresorufin O-deethylase (EROD) activity responses of greenback flounder Rhombosolea tapirina to contaminated marine sediment and diet. Aquat Toxicol 54, 231-247.

Nixon, S.W., Buckley, B.A., 2002. "A strikingly rich zone" - nutrient enrichment and secondary production in coastal marine ecosystems. Estuaries 25, 782-796.

Northington, R.M., Hershey, A.E., 2006. Effects of stream restoration and wastewater treatment plant effluent on fish communities in urban streams. Freshwater Biol 51, 1959-1973.

Oczkowski, A.J., Nixon, S.W., Granger, S.L., El-Sayed, A.F.M., McKinney, R.A., 2009. Anthropogenic enhancement of Egypt's Mediterranean fishery. Proceedings of the National Academy of Sciences of the United States of America 106, 1364-1367.

Orth, R.J., Carruthers, T.J.B., Dennison, W.C., Duarte, C.M., Fourqurean, J.W., Heck, K.L., Hughes, A.R., Kendrick, G.A., Kenworthy, W.J., Olyarnik, S., Short, F.T., Waycott, M., Williams, S.L., 2006. A global crisis for seagrass ecosystems. Bioscience 56, 987-996.

Pitt, K.A., Connolly, R.M., Maxwell, P., 2009. Redistribution of sewage-nitrogen in estuarine food webs following sewage treatment upgrades. Mar Pollut Bull 58, 573-580.

Reopanichkul, P., Schlacher, T.A., Carter, R.W., Worachananant, S., 2009. Sewage impacts coral reefs at multiple levels of ecological organization. Mar Pollut Bull 58, 1356-1362.

Risk, M.J., Sherwood, O.A., Nairn, R., Gibbons, C., 2009. Tracking the record of sewage discharge off Jeddah, Saudi Arabia, since 1950, using stable isotope records from antipatharians. Marine Ecology-Progress Series 397, 219-226.

Schlacher, T.A., Connolly, R.M., 2009. Land-ocean coupling of carbon and nitrogen fluxes on sandy beaches. Ecosystems 12, 311-321.

Schlacher, T.A., Liddell, B., Gaston, T.F., Schlacher-Hoenlinger, M., 2005. Fish track wastewater pollution to estuaries. Oecologia 144, 570-584.

Schlacher, T.A., Mondon, J.A., Connolly, R.M., 2007. Estuarine fish health assessment: Evidence of wastewater impacts based on nitrogen isotopes and histopathology. Mar Pollut Bull 54, 1762-1776.

Schlacher, T.A., Skillington, A.J., Connolly, R.M., Robinson, W., Gaston, T.F., 2008. Coupling between marine plankton and freshwater flow in the plumes off a small estuary. International Review of Hydrobiology 93, 641658.

Shepherd, S.A., Sprigg, R.C., 1976. Substrate, sediments and subtidal ecology of Gulf St Vincent and Investigator Strait, in: Twidale, C.R., Tyler, M.J., Webb, B.P. (Eds.), Natural history of the Adelaide Region. Royal Society of South Australia, Adelaide, pp. 161-174. 
Skinner, M.A., Courtenay, S.C., Parker, W.R., Curry, R.A., 2012. Stable isotopic assessment of site fidelity of mummichogs, Fundulus heteroclitus, exposed to multiple anthropogenic inputs. Environ Biol Fish 94, 695-706.

Touchette, B.W., Burkholder, J.A.M., 2000. Review of nitrogen and phosphorus metabolism in seagrasses. Journal of experimental marine biology and ecology 250, 133-167.

Tucker, J., Sheats, N., Giblin, A.E., Hopkinson, C.S., Montoya, J.P., 1999. Using stable isotopes to trace sewage-derived material through Boston Harbor and Massachusetts Bay. Mar Environ Res 48, 353-375.

Vanderklift, M.A., Wernberg, T., 2010. Stable isotopes reveal a consistent consumer-diet relationship across hundreds of kilometres. Marine Ecology-Progress Series 403, 53-61.

Vitousek, P.M., Aber, J.D., Howarth, R.W., Likens, G.E., Matson, P.A., Schindler, D.W., Schlesinger, W.H., Tilman, D.G., 1997. Human alteration of the global nitrogen cycle: Sources and consequences. Ecol Appl 7, 737-750.

Waycott, M., Duarte, C.M., Carruthers, T.J.B., Orth, R.J., Dennison, W.C., Olyarnik, S., Calladine, A., Fourqurean, J.W., Heck, K.L., Hughes, A.R., Kendrick, G.A., Kenworthy, W.J., Short, F.T., Williams, S.L., 2009. Accelerating loss of seagrasses across the globe threatens coastal ecosystems. Proceedings of the National Academy of Sciences of the United States of America 106, 12377-12381.

Winning, M., Connolly, R., Loneragan, N., Bunn, S., 1999. ${ }^{15} \mathrm{~N}$ enrichment as a method of separating the isotopic signatures of seagrass and its epiphytes for food web analysis. Mar Ecol Prog Ser 189, 289-294.

Wulff, F., Eyre, B.D., Johnstone, R., 2011. Nitrogen versus phosphorus limitation in a subtropical coastal embayment (Moreton Bay; Australia): Implications for management. Ecological Modelling 222, 120-130. 